\title{
A Laboratory Breeding Method of Ixodes ricinus gibbosus Nuttall, 1916
}

MÉTHOde D'ÉLEVAGE EN LABORATOIRE D'Ixodes ricinus gibbosus Nuttall, 1916)

\author{
by R. CWILICH and A. HADANI
}

Ixodes ricinus gibbosus (I.r.g.) was found in the northern part of Israel, mainly on goats and sheep in winter (December-March). Its occurrence was related by local shepherds to paralytic phenomena in these animals.

In order to study the possible pathogenic role of I.r.g. a method for the breeding of this tick in the laboratory was established, the details of which are given below.

Engorged females, collected from goats, were maintained singly in test-tubes, in which high degree of humidity was obtained by partly filling the test tube with water and then pushing a cotton plug, tightly pressed, until touching the level of the water. The female tick rested on the cotton. Oviposition started, under room conditions, in a few days - ten weeks and larva hatched in about 3 months. In spite of the development of moulds, eggs and larvae seem to develop normally. The larvae usually seek the humid parts of the test tube often crowding and even penetrating the cotton towards the water.

Lavarl survival under such conditions is very long (4 months and more). However, larva died shortly after water completely evaporates.

Few of the larvae engorged on the gerbil (Meriones tristrami) when applied similarly to Hyalomma and Rhipicephalus (described elsewhere). Satisfactory results were only obtained when the feeding method was modified as to simulate conditions prevailing in the tick's natural habitat.

The gerbil was confined in an iron mesh cylinder on a tray with moistened cotton, the whole being put at $17^{\circ}$ C. I.r.g. larvae, spread on the animal, immediately attached to the head, ears, interdigital skin and tail. Fully engorged larvae detached in 4-8 days and maintained in test tubes arranged as mentioned above with a rolled piece of gazwatt so as to permit their movement in the test tube well off the moistened and mouldy cotton at the bottom. Engorged larvae thus maintained at $28^{\circ} \mathrm{C}$ gave rise to nymphs in 6 weeks.

Nymphs were not inclined to feed unless maintained beforehand at $11^{\circ} \mathrm{C}$ for 10-14 days. The nymphs, being ready to feed, were repulsed by the gerbil and were 
found to attach readily on to a rabbit's ear, confined in a linen bag with moistened cotton. Fully engorged nymphs start to detach from the ear on the 8 th day after attachment, and kept in test tubes as described above $28^{\circ} \mathrm{C}$, moulted to adults 30 days afterwards.

It thus seems that using gerbils and rabbits under well defined conditions of temperature and humidity, it should be possible to breed Ixodes ricinus gibbosus in the laboratory. However, the duration and survival of both the parasitic and nonparasitic stages should be still studied oarefully.

Other species of ticks, well adapted to particular ecological conditions, might be reared in the laboratory using similar methods.

\section{Résumé}

I. ricinus gibbosus a été trouvé au nord d'Israël, principalement sur des chèvres et des moutons en hiver (décembre à mars). Les bergers de la région l'impliquent dans les syndromes de paralysie observés chez ces animaux.

L'élevage de cette tique au laboratoire a été réalisé de la façon suivante :

Des femelles gorgées, prélevées sur des chèvres, sont placées isolément dans des tubes-tests, partiellement remplis d'eau et bourrés de coton jusqu'à absorption de cette eau au préalable. L'oviposition débute après quelques jours; les larves éclosent après 3 mois, malgré les moisissures du coton, et peuvent survivre plus de 4 mois si le coton reste humide.

Les larves sont nourries sur des gerbilles (fixation au niveau de la tête, des oreilles, de la peau interdigitale, de la queue), dans des conditions particulières d'humidité et de température $\left(17^{\circ} \mathrm{C}\right)$. Elles se détachent au bout de 4 à 8 jours.

Replacées dans les tubes précédemment décrits, avec un rouleau de «gaz-watt » au-dessus du coton humide pour leur permettre de se mouvoir, elles se transforment en nymphes en 6 semaines, à $28^{\circ} \mathrm{C}$.

Ces nymphes refusent de se nourrir sur la gerbille, mais elles acceptent le lapin si, préalablement, elles ont été maintenues à $11^{\circ} \mathrm{C}$ pendant 10 à 14 jours. Le repas dure au minimum 8 jours.

Les nymphes détachées et gorgées sont conservées dans les tubes-tests à une température de $28^{\circ} \mathrm{C}$ au moins ; elles deviennent adultes au bout de 30 jours.

L'usage alterné de la gerbille et du lapin, dans des conditions définies de température et d'humidité, permet done d'entretenir au laboratoire l'élevage d'Ixodes ricinus gibbosus. Cependant la durée et la survivance des stades parasitaires et non parasitaires demandent à être surveillées de très près.

\section{(Department of Parasitology, Veterinary Institute, Bet-Dagan, Israël)}

